Introduction to Special Issue on 'refugee crisis'

The European Union and the refugee 'crisis':

Inclusion, challenges, and responses

Rahul Sambaraju ${ }^{1}$

Chris McVittie ${ }^{2}$

${ }^{1}$ University of Limerick

${ }^{2}$ Queen Margaret University 
For community and applied social psychology, issues of group memberships and intergroup relations in real-world settings are central concerns. One particular focus of study has been that of how the construction of social groups to delineate the criteria that distinguish members and potential members from non-members. Nowhere is this more so than in relation to nations and the attribution of national identities. As Condor (2000) notes, a reference to national identity functions to include certain people while simultaneously excluding those who do not meet the criteria that have been specified. The outcome of this, in so far as regards nations, is that we come to understand the world around us in terms of nations/nationstates and wider transnational collectives (Billig, 1995; Condor, 2000). The specific forms of these groups of course changes over time: events following the vote by UK citizens on 23 June 2016 to leave the European Union point to the sorts of changes that can occur. Yet, notwithstanding that the precise forms of nations and transnational entities can change, such changes rarely trouble the recurring understanding of the world around us as comprising a collection of national states with identifiable members, each with their own identities. For individuals who are identified as belonging to a nation state, this routine and pervasive construction of nation states works to confer upon members the entitlements that are commonly associated with membership. At the same time, however, another outcome is the ready identification of 'others' as those who do not belong to certain nations and transnational collectives. Those who leave their countries of origin to seek refuge or asylum are routinely treated in these ways in legitimating practices and policies that exclude them from belonging to other nation states and that preclude them the entitlements allowed to members. This special issue brings together social psychological work on the refugee 'crisis' in the European Union (EU), looking particularly at the inclusion / contingent inclusion / exclusion of those leaving their countries of origin to seek refuge in the EU, how such inclusion or exclusion is warranted or negotiated, and if and how these practices are presented as a 'refugee crisis'.

\section{The 'crisis':}

Over recent years the displacement of individuals on a global scale from their places of origin has been ever-increasing. As the United Nations High Commissioner for Refugees (UNHCR) states, 2015 was the year when most number of people were displaced since World War II 
(Herwig, 2016). The UNHCR figures show that at present we experience unprecedented levels of displacement with 65.3 million people around the wold being forced to leave home (UNHCR, 2017; see also AlJazeera, 2017). Of these 21.3 million are refugees and another 10 million are stateless - those who have been denied a nationality. While $53 \%$ of refugees originate from Somalia, Afghanistan and Syria, 4.9 million come from Syria alone.

These figures readily demonstrate a 'crisis', but for whom? In 2015, over one million individuals crossed the Mediterranean Sea from North Africa seeking resettlement in the European Union. Many others attempting to make the crossing failed to survive the journey. Nonetheless, within the EU this influx of migrants prompted announcements of a 'migration crisis' / refugee 'crisis' / humanitarian 'crisis' (for more on this please see Goodman, 2017 current issue). In September 2015, the EU avowed accepting 160,000 refugees under the EU Resettlement and Relocation Programme that involves various EU member states taking up a certain number of refugees and asylum applications alongside other measures (MetcafleHough, 2015). Those to be accepted, however, are by no means those who have risked their lives in making the crossing. In terms of the Turkey-EU deal, agreed on 18 March 2016, migrants who crossed by sea to the Greek islands have subsequently been returned to Turkey in exchange for the EU agreeing to resettle Syrian refugees living in Turkey (AlJazeera, 2017). Perhaps (in part) reflecting the difficulties in gaining acceptance in the EU, the number of migrants crossing the Mediterranean Sea in 2016 dropped to approximately 364,000 , one third of the 2015 number. It should be noted though that, despite this drop in the number of those arriving in the EU, deaths among those attempting the crossing rose by 300 or about $34 \%$. Thus, although currently there is less talk of a 'refugee crisis' in the EU from policy-makers, for those seeking to migrate to the EU the crisis continues.

\section{The social psychology of migration}

Social psychologists are interested in examining how identification with national and transnational entities is formed, constituted and constructed and the outcomes for this for practical activities (McKinlay \& McVittie, 2008). In particular, social psychologists have examined how peoples' identification has outcomes for allowing or restricting access to people migrating or forced to migrate (Every \& Augoustinos, 2008; O'Doherty \& Augoustinos, 2008). Social psychological studies of exclusion / inclusion have examined issues around peoples who migrate or are forced to migrate through studying constructions of 
nations and those who belong within these and who do not (Lyons, Madden, Chamberlain, \& Carr, 2011), constructions of those who migrate or are forced to migrate (Lynn \& Lea, 2003) and wider states of affairs (Gibson \& Hamilton, 2011). Alongside this a notable amount of work also criticizes how identifications and constructions are inherently biased in the favour of those with power, status or towards maintaining a hegemonic status-quo (KhosraviNik, 2010).

Research shows that issues of exclusion / inclusion are generally contingent on routine aspects of social identification, categorization and allocation of rights and entitlements. This means that examinations of current goings-on events need to consider how various identifications are offered, the rights and entitlements on offer, and the relations between these. Some of the relevant findings are discussed below.

Researchers show that refugees are routinely described in problematic ways in warranting their limited or contingent inclusion (Goodman \& Burke, 2010; Goodman \& Speer, 2007; Kirkwood, Goodman, McVittie, \& McKinlay, 2015). Findings here point to challenging the legitimacy of those seeking asylum, through for instance, differentiating between those who are 'genuine' and 'bogus' (Lynn \& Lea, 2003). Alternatively, researchers also show how limited inclusion is warranted and justified through offering particular versions of the nation (O'Doherty \& Augoustinos, 2008). Alongside such findings, researchers show that these warrants for exclusion are offered in ways to mitigate implications of appearing prejudiced or racist. For instance, Goodman and Burke (2010) show how negotiating inclusion of asylum seekers involves suppression of racist implications. The authors term this 'discursive deracialisation', following Reeves (1983). In addition to denials of racism and disclaimers such as 'I'm not a racist, but...' (van Dijk, 1992), deracialisation involves attributing issues with refugee presence in their nations to other factors such as economy (Goodman, Burke, Liebling, \& Zasada, 2014), thereby mitigating implications of being against the presence of refugees or asylum-seekers in their nations.

These features of exclusion / inclusion are particularly relevant in elite and public settings. Non-nation others are always subject to policies of the arrival nations. In settings such as the media (Leudar, Hayes, Nekvapil, \& Baker, 2008), in political settings such as parliaments (Every \& Augoustinos, 2008) and other public deliberations (Burke \& Goodman, 2012), policies that exclude / include those seeking asylum or refuge become central objects of focus. Furthermore, discussions in these settings are routinely held to inform and shape 
Introduction to Special Issue on 'refugee crisis'

broader understandings and policy (van Dijk, 2009). It is then relevant that social psychologists examine practices in these settings as the seven papers in this special issue do.

\section{Papers in this special issue}

The present context is unique in its scope, its pervasive characterization as a 'crisis' and the widespread calls for support, sympathy and action. This context then offers scope for inclusive actions to offer refuge or asylum to those in need. However, as mentioned above, and as will be shown in the papers in this special issue, inclusion of these peoples is severely restricted. Goodman's (2017) analysis examines constructions of the events in major UK newspapers changed over the course of specific events in Europe. The analysis demonstrates how versions of the 'crisis' at hand and categorisations of those seeking refuge - either as migrants or as refugees - evolved from constructions that presented them as problematic for the UK to ones that were more favourable, positive and inclusion-worthy, respectively. Goodman shows that these constructions were contingent on other ongoing events in Europe such as the terrorist attacks in Paris in 2015, following which the constructions of the 'crisis' and categorisations of those seeking refuge offer problematic inferences. However, Goodman's analysis points to two important findings. First, the events were consistently reported as a 'crisis' and therefore actionable. Second, the pervasive sympathetic categorisations of refugees, were unique thus far in studies on inclusion / exclusion of those seeking asylum or refuge. The analysis highlights the flexible and contingent means of constructing and categorising those seeking refuge and the implications of their inclusion.

Kirkwood (2017) examines discussions in UK House of Commons, the Scottish Parliament, Northern Ireland Assembly and Welsh Assembly on the 'refugee crisis'. The analysis here points to how those seeking refuge or asylum were treated as 'human'. In contrast to previous findings that examine processes of dehumanising, here UK parliamentarians offered pointedly humanised versions of these peoples. This was particularly accomplished through the use of mundane descriptions and categorisations of these peoples. Kirkwood shows how these allowed for expressions of sympathy towards people seeking asylum or refuge and therefore their inclusion. However, sympathy invoking and affirming accounts sat side-by-side with accounts that offered restrictive inclusion of refugees. Kirkwood draws attention to how these accounts serve to be paternalistic. This attends to a particular issue with political avowals: treating 'others' as human, while refraining from providing support or access to those beyond national borders. 
Introduction to Special Issue on 'refugee crisis'

Bates (2017) examines media coverage of those offered asylum. His analysis similarly shows that avowals of sympathy sit side-by-side with more problematic versions of inclusion. In an analysis of UK print media constructions of a particularly problematic event for those already offered asylum in Middlesbrough, UK, called 'The Red Door Controversy', Bates shows that avowals of sympathy limit more potent forms of inclusion. Through a critical discursive approach (KhosraviNik, 2010), Bates shows that discrimination faced by those offered asylum was ascribed to marginal groups such as 'youths' or 'thugs', than being included in a more realistic account of relevant factors. Bates, argues that while media reporting was sympathetic and understanding of the plight of those offered asylum, this did little to engage with alternative accounts of discrimination. These accounts served to obscure examination of structural racism and presented the media as sympathetic agencies. Thus, Bates argues that even sympathetic media outlets can perpetuate exclusionary actions.

This aspect of avowing sympathy for those seeking refuge is further explored by Nightingale, Quayle and Muldoon (2017). Nightingale et al (2017) examine talk on a publicly broadcast Irish radio call-in programme. Their examination of sympathetic talk on the programme takes-up the case of inclusion-advocacy and how this might or might not take place. Taking a critical discursive psychological approach they examine affective-discursive practices (Wetherell, 2012) engaged in by callers. They show how these radio calls involve avowals of sympathy alongside issues with warranting inclusion. Callers avow heartfelt grief and sympathy for the plight of those seeking refuge and asylum. However, they argue that callers refrain from offering inclusion avowals or advocate minimal inclusion. The authors highlight the role of identification with the nation and its associated limits in advocating inclusion.

Mahendran (2017) takes-up the issue of orienting to the boundedness of nations and national identification. In taking-up Bakhtin's (1981) ideas of dialogic self and how it allows for articulating self-other-world relations, Mahendran draws attention to how 'empathy' can alternatively be understood as 'outsideness' - the ability to take other's position, return to the self and act for the other person'. Her analysis of interview-talk, on concerns with their mobility, the EU and citizenship, points to the ways in which this takes place. She identifies three 'dimensions' of, what she calls, 'one world narrative': a) people distance themselves from identifying with any particular social group; b) people treat 'borders' and nationboundedness as constructed and therefore problematic; instead they present themselves as 'citizens' of the world, and (c) people highlight the accidental aspect of being alive or born. 
Through identification of these dimensions, her analysis shows the relevance of one-world narrative in advocating inclusion.

However, these aspects of global belonging may not always be sustained or relevant. In other settings, a narrower understanding of who 'we' are seems to be at play in negotiating inclusion and rights. Andreouli and colleagues (Andreouli, Figgou, Kadianaki, Sapountzis, \& Xenitidou, 2017) show how transnational relations and connections are variously constructed in negotiating issues of citizenship and belonging. The authors examine issues around citizenship and belonging in the context of Greece, where people have had to directly engage with migrants and refugees more so than in other EU nations, partly because of EU's own policies. They analyse online public deliberations about citizenship rights for migrants in Greece. Their analysis points to the relevance of examining how nation states in Europe can be or are oriented to as prototypically European, or, as unique in their own right. This transnational identification can either be used to warrant inclusion and further rights for migrants or for the reverse. They highlight the unique position of Greece as straddling the 'West' and the 'East' and its relevance for reconfiguring inclusion of migrants. Furthermore, the authors note that for those posting to the website Europe was treated as synonymous with 'Western Europe'. The posters did not readily see Greece as European. Rather they workedup Greece as falling short of being European or as aiming to avoid the European example where migrants are ghettoised. In this way, negotiation of citizens' and migrants' rights centrally involved accounts that went beyond ready national identification. Rather these involved transnational identifications and distancing.

The final paper in this special issue examines the relevance of national and transnational talk in negotiating inclusion of refugees. Sambaraju, McVittie and Nolan (2017), examine how warrants for inclusion of refugees were made in the Dáil Éireann (Irish Parliament), during the calendar year 2015. Their examination shows that Deputies (elected members of the Dáil Éireann) warranted and negotiated warrants for inclusion of refugees through specific forms of talk about Ireland and the EU. Deputies made relevant particular aspects of Ireland in treating ongoing inclusion efforts as inadequate and warranting further inclusion. These were managed by framing the issues in terms of the EU or as European issues. This alongside favourable versions of Ireland's ongoing efforts worked to mitigate responsibility for limited inclusion. The authors point to the role of treating not merely national entities but also transnational entities as ‘imagined communities' (Anderson, 1983).

Taken together, these papers offer a thorough and powerful examination of constructions of those seeking refuge and more importantly the practices of those in a 
position to offer refuge. Findings here point to two central practices involved in negotiating inclusion of refugees. First, avowals of sympathy were made alongside limited or restricted calls for inclusion (Hanson-Easey \& Augoustinos, 2011). While calls for exclusion were minimal, advocating inclusion was not forthcoming either. These avowals then are one way to mitigate problematic inferences of being seen as not wanting to help those in need of refuge. Obviously, such an inference in the current context is severely problematic in contexts of public discourse. Second, negotiation of inclusion was made outwith boundaries and limits of the nation (O'Doherty \& Augoustinos, 2008). As Sambaraju et al (2017) show, national identification and belonging, although form ready resources in negotiating inclusion, were either reconfigured or transcended in these settings.

\section{Applications for inclusion-advocacy:}

These findings point to certain challenges and opportunities for inclusion-advocacy. First, Sympathetic talk, while favourable, can restrict inclusion-advocacy. As Goodman (2017) points out, this poses a particular problem for inclusion-advocates. However, emphasizing such talk can have obvious benefits. Second, the relevance of transnationalism offers unique opportunities for inclusion-advocacy through overcoming national identification as the only frame for discussing inclusion (Sambaraju et al, 2017). Third, these findings also highlight issues with liberal humanitarianism, which although advocates inclusion and equal treatment can engender discourses of paternalism (Nightingale et al, 2017) and practices of limited inclusion (Kirkwood, 2017). In this way, the collection of papers here goes beyond theoretical concerns. It is also worth noting that a joint action plan by the UNHCR and International Organisation for Migration, Regional Refugee and Migrant Response Plan for Europe (Migration, 2016), similarly highlights aspects of solidarity and transnational coordination in addressing inclusion concerns and rehabilitation. A major difficulty, however, remains that as seen in all the papers in this Special Issue: sympathy for refugees is contingent upon the context in which is located. As for example Goodman (2017) notes, the sympathy expressed towards refugees can end as abruptly as it arises. Thus, unless and until the 'crisis' is treated as one for those forced to migrate rather than for the states to which they are migrating, inclusion-advocacy will remain a challenge.

\section{Acknowledgements:}

We are extremely grateful to all contributors to this special issue and their collaborators for their efforts. We are particularly thankful to the reviewers who helped with our efforts in 
Introduction to Special Issue on 'refugee crisis'

developing this collection of papers. Finally, we are grateful to the editorial team for giving us this opportunity and their support in the production of this special issue.

We are particularly grateful to Professor Andrew McKinlay for his efforts at editing this special issue. 
Introduction to Special Issue on 'refugee crisis'

\section{References}

AlJazeera. (2017). Number of refugees reaching Europe plunged in 2016. Retrieved 30/01, 2017, from http://www.aljazeera.com/news/2017/01/number-refugees-reachingeurope-plunged-2016-170106132732972.html

Anderson, B. (1983). Imagined Communities: Reflections on the origin and spread of nationalism. London: Verso.

Andreouli, E., Figgou, L., Kadianaki, I., Sapountzis, A., \& Xenitidou, M. (2017). 'Europe' in Greece: Lay constructions of Europe in the context of Greek immigration debates. Journal of Community \& Applied Social Psychology, 27(2).

Bakhtin, M. M. (1981). The Dialogic Imagination. Austin, USA: University of Texas Press.

Bates, D. (2017). The 'Red Door' Controversy: Middlesbrough's asylum seekers and the discursive politics of racism. Journal of Community \& Applied Social Psychology, 27(2).

Billig, M. (1995). Banal Nationalism. London: Sage.

Burke, S., \& Goodman, S. (2012). 'Bring back Hitler's gas chambers': Asylum seeking, Nazis and Facebook - a discursive analysis. Discourse \& Society, 23(1), 19-33.

Condor, S. (2000). Pride and prejudice: Identity management in English people's talk about 'this country'. Discourse \& Society, 11, 175-205 .

Every, D., \& Augoustinos, M. (2008). Constructions of Australia in pro- and anti-asylum seeker political discourse. Nations and Nationalism, 14(3), 562-580. doi: $10.1111 / \mathrm{j} .1469-8129.2008 .00356 . \mathrm{x}$

Gibson, S., \& Hamilton, L. (2011). The rhetorical construction of polity membership: Identity, culture and citizenship in young people's discussions of immigration in northern England. Journal of Community and Applied Social Psychology. 21(3), 228242.

Goodman, S. (2017). The evolving (re)categorisations of refugees throughout the 'Refugee/Migrant crisis'. Journal of Community \& Applied Social Psychology, 27(2).

Goodman, S., \& Burke, S. (2010). Discursive deracialization in talk about asylum seeking. Journal of Community \& Applied Social Psychology, 21(2), 111-123. 
Introduction to Special Issue on 'refugee crisis'

Goodman, S., Burke, S., Liebling, H., \& Zasada, D. (2014). 'I'm not happy, but I'm okay': How asylum seekers manage talk about difficulties in their host country. Critical Discourse Studies, 11(1), 19-34. doi: 10.1080/17405904.2013.836114

Goodman, S., \& Speer, S. (2007). Category use in the construction of asylum-seekers. Critical Discourse Studies., 4(2), 165-185. doi: 10.1080/17405900701464832

Hanson-Easey, S., \& Augoustinos, M. (2011). Complaining about humanitarian refugees: The role of sympathy talk in the design of complaints on talkback radio. Discourse \& Communication, 5(3), 247-271. doi: https://doi.org/10.1177/1750481311405588

Herwig, C. (2016). Global Trends Forced Displacement in 2015. Geneva, Switzerland: United Nations High Commissoner for Refugees.

Internation Organization for Migration. (2016). Regional Refugee and Migrant Response Plan for Europe - January to December 2017. London, United Kingdom: Internation Organization for Migration.

KhosraviNik, M. (2010). The representation of refugees, asylum seekers and immigrants in British newspapers: A critical discourse analysis. Journal of Language and Politics, 9(1), 1-28. doi: 10.1075/jlp.9.1.01kho

Kirkwood, S. (2017). The humanisation of refugees: A discourse analysis of UK parliamentary debates on the European refugee 'crisis'. Journal of Community \& Applied Social Psychology, 27(2).

Kirkwood, S., Goodman, S., McVittie, C., \& McKinlay, A. (2015). The Language of Asylum: Refugees and Discourse. UK: Palgrave Macmillan.

Leudar, I., Hayes, J., Nekvapil, J., \& Turner Baker, J. (2008). Hostility themes in media, community and refugee narratives. Discourse \& Society, 19(2), 187-221. doi: $10.1177 / 0957926507085952$

Lynn, N., \& Lea, S. (2003). 'A phantom menace and the new Aparthied': The social construction of asylum-seekers in the United Kingdom. Discourse \& Society, 14(4), 425-452.

Lyons, A. C., Madden, H., Chamberlain, K., \& Carr, S. (2011). 'It's not really us discriminating against immigrants, it's more telling people how to fit in': Constructing the nation in immigration talk in New Zealand. Journal of Community \& Applied Social Psychology, 21(1), 14-27. doi: 10.1002/casp.1051

Mahendran, K. (2017). Public narratives on human mobility: countering technocratic and humanitarian refugee narratives with a 'one world' solidarity narrative. Journal of Community \& Applied Social Psychology, 27(2). 
Introduction to Special Issue on 'refugee crisis'

McKinlay, A., \& McVittie, C. (2008). Social Psychology \& Discourse. Sussex: WIleyBlackwell.

Metcafle-Hough, V. (2015). The migration crisis? Facts, challenges and possible solutions. London, UK: Overseas Development Institute, UK.

Nightingale, A., Quayle, M., \& Muldoon, O. (2017). "It's just heart breaking": Doing inclusive political solidarity or ambivalent paternalism through sympathetic discourse within the "refugee crisis" debate. Journal of Community \& Applied Social Psychology, 27(2).

O'Doherty, K., \& Augoustinos, M. (2008). Protecting the nation: Nationalist rhetoric on asylum seekers and the Tampa. Journal of Community and Applied Social Psychology., 18, 576-592. doi: 10.1002/casp.973

Reeves, F. (1983). British racial discourse: A study of British political discourse about race and race-related matters. Cambridge: Cambridge University Press.

Sambaraju, R., McVittie, C. \& Nolan, P. (2017). 'This is an EU crisis requiring an EU solution': Nation and transnational talk in negotiating warrants for further inclusion of refugees. Journal of Community \& Applied Social Psychology, 27(2).

UNHCR. (2017). Figures at a Glance. Retrieved 04/02, 2017, from http://www.unhcr.org/figures-at-a-glance.html

van Dijk, T. (1992). Discourse and the denial of racism. Discourse and Society, 3(1), 87-118. doi: $10.1177 / 0957926592003001005$

van Dijk, T. (2009). Society and discourse: How social contexts influence text and talk. Cambridge: UK: Cambridge University Press.

Wetherell, M. (2012). Affect and Emotion: A New Social Science Understanding. London, UK: Sage. 